\title{
Molecular analysis of ompA gene Pasteurella multocida Indonesia local isolates
}

\author{
A. Dewi ${ }^{1}$, A. Estoepangestie ${ }^{2}$, S. Suwarno ${ }^{3}$, D. Handijatno ${ }^{4}$, R. Ernawati ${ }^{5}$ and W. Tyasningsih $^{6}$ \\ 1,2 Department of Veterinary Public Health, ${ }^{3-6}$ Department of Veterinary Microbiology, Faculty of Veterinary Medicine, \\ Universitas Airlangga, Kampus C Universitas Airlangga, 60115, Surabaya, Indonesia
}

\begin{tabular}{l} 
Article information \\
\hline Article history: \\
Received July 21, 2019 \\
Accepted October 05, 2019 \\
Available online March 15, 2021 \\
\hline Keywords: \\
Pasteurella multocida \\
ompA gene \\
nucleotide \\
local isolate \\
\hline Correspondence: \\
A. Dewi \\
arini1992@ gmsail.com
\end{tabular}

Article information

rticle history

Accepted October 05, 2019

Available online March 15, 202

\begin{abstract}
The aim of this research was to analyze ompA molecular gene of Pasteurella multocida buffalo isolate and bovine isolate from Nusa Tenggara Timur, Indonesia and Katha strain isolate from hemorrhagic septicemia vaccine. Determinant of $P$. multocida local isolates ompA gene amplification sequencing PCR then conducted to see the sequence of nucleotide sequences of ompA gene. The results of PCR amplification showed an amplicon of $559 \mathrm{bp}$ of all isolates. The homology analysis result of the isolates ranged from $93-100 \%$ with 13 P. multocida isolates from GenBank, and phylogenetic tree analysis shows that buffalo isolate was closely related to Katha strain, Iran, India and China isolate. Whereas bovine isolate far enough with buffalo and Katha strain isolate. Nucleotide sequences were compared to amino acids then by the method of Kolaskar and Tongaonkar antigenicity predicted antigens in $P$. multocida. B cell epitope predictions from local isolates and Katha strain were found in five peptides QVSPVFAG, IPELALRVEYQ, GQSVYVPEVVSKT, LKSASVAVAG, and ANYLVAKG.
\end{abstract}

DOI: 10.33899/ijvs.2019.125934.1191, (C2021, College of Veterinary Medicine, University of Mosul.

This is an open access article under the CC BY 4.0 license (http://creativecommons.org/licenses/by/4.0/).

\section{Introduction}

Haemorrhagic Septicaemia (HS) or snoring disease is an infectious disease caused by acute to fatal bacteria in ruminants including cattle and buffaloes in tropical countries, including Asia and the African continent. The causes of this disease are Pasteurella multocida type B:2 in Southeast Asia and E:2 in Africa (1). Haemorrhagic Septicaemia has spread in all regions of the world that have high rainfall, including Indonesia, Malaysia, the Philippines and Thailand (2). The losses caused by HS disease reach 100,000 dead each year in several Asian regions (3). The control of HS in Indonesia uses the Katha vaccine, the inactive vaccine of $P$. multocida strain Katha from Burma. The Katha vaccine provides immunity for five months and is injected twice a year (2). Recently recombinant vaccines have been widely studied manufacture vaccinesand recombinant DNA sequencing technology have created shortly knew raft in vaccines epitope-based, which is able to stimulate specific immune responses, has been identified and used to achieve advanced vaccine formulation, which can replace the overall formulation pathogens (4). Epitope-based vaccines are specific, capable of avoiding unwanted, producing immune responses long immunity, and the price is cheaper (5). The outer membrane protein encoding genes have been widely studied and some of them are used as the basis for making vaccines which heterologically can protect against infection with several strains of P.multocida (6), one of which is ompA can be used as a vaccine because it is immunogenic $(7,8)$. P.multocida ompA gene consists of 1047 to 1077 nucleotides that encode proteins of 349 to 360 amino acids. Some studies state that 
ompA is an immunogenic, surface-exposed, and expressed antigen in vivo (9), and has been shown to cause antibodies to P.multocida in cattle $(10,11)$ and mice $(9)$. The OMP with a molecular weight of $37 \mathrm{kDa}$ was an immunodominant protein in P.multocida isolates that caused HS (12). The specific part of the P.multocida encoding gene with a molecular weight of $37 \mathrm{kDa}$ can cloned and expressed that its recombinant proteins act as specific antigen for development diagnostic test (13). $37 \mathrm{kDa}$ ompA from P.multocida isolates were obtained by heating $100^{\circ} \mathrm{C}$ for 5 minutes by SDS-PAGE (14).

The aim of this research was to analyze ompA molecular gene of Pasteurella multocida buffalo isolate and bovine isolate from Nusa Tenggara Timur, Indonesia and Katha strain isolate from hemorrhagic septicemia vaccine.

\section{Materials and methods}

\section{Preparation of bacterial isolates}

Pasteurella multocida local isolates from buffalo and bovine were obtained from the Bali Veterinary Center in Denpasar and P.multocida Katha strain isolate from the haemorrhagic septicaemia vaccine. Local isolates are cultured in blood agar. The reconfirm tests are biochemical test: Triple Sugar Iron Agar, Sulfide Indole Motility, Simmon's Citrate Agar, and urea; gram staining; and growth on Mac ConkeyAgar.

\section{PCR amplification}

Pasteurella multocida local isolates and Katha strain isolate were determinant by polymerase chain reaction amplification with specific primers, which is modification of research $(15,16)$. Forward: 5'CGCATAGCACTCAAGTTTCTCC 3 ' and Reverse: 5'CGATCGTCAGCTAAACATGC 3' with 559 bp amplicon. Then the genomic DNA of P.multocida isolates are obtained by DNA extraction using genomic DNA purification kit GeneJET of Thermo Fisher Scientific.The PCR product amounts to $25 \mu \mathrm{l}$ which consists of $5 \mu 1$ DNA templates, $1 \mu 1$ each primer, $12.5 \mu 1$ master mix, and $0.5 \mu 1$ aquades are then inserted into the microtube. Initial denaturation at $94^{\circ} \mathrm{C}$ for five minutes, denaturation at $94^{\circ} \mathrm{C}$ for 30 seconds, annealing at $57^{\circ} \mathrm{C}$ for 30 seconds, elongation at $72^{\circ} \mathrm{C}$ for 30 seconds, and final elongation of $72^{\circ} \mathrm{C}$ for five minutes with 35 cycles.

\section{Nucleotide Sequences Analysis}

Nucleotide sequencing of P.multocida local isolates and Katha strain isolate PCR product at CV Biotek Prima Indoplus, Sidoarjo. The nucleotide sequence homology analysis using Nucleotide BLAST program at http://www.ncbi.nlm.nih.gov, as well as phylogenetic tree analysis by Mega- $\mathrm{X}$ using Neighboring joining method and bootstrapped to ruminant isolates from several countries in the world from NCBI GenBank (CP017961.1, JQ859919.1,
AY903603.1, HQ829458.1, AY643794.1, AY643797.1, KU342614.1，KU342613.1，KU342627.1，JQ230325.1, KU342629.1，JX473017.1， and KU342624.1) and predictions using the Ellipro Epitope Program: Epitope Prediction Antibody on https://www.iedb.org/ with the Kolaskar and Tongaonkar antigencity methods.

\section{Results}

Pasteurella multocida local isolates colonies looks gray, has a distinctive smell and no hemolytic the media of Blood Agar which has been incubated at $37^{\circ} \mathrm{C}$ for 24 h. Biochemical tests showed the properties of $P$. multocida bacteria and Gram staining appeared to be red colony, coccobacilli, and encapsulated. The results of PCR amplification of local isolates and Katha strain isolate using forward and reverse primers showed $559 \mathrm{bp}$ which were in accordance with the number of amplicon targets used in the manufacture of ompA encoding gene primers (Figure 1).

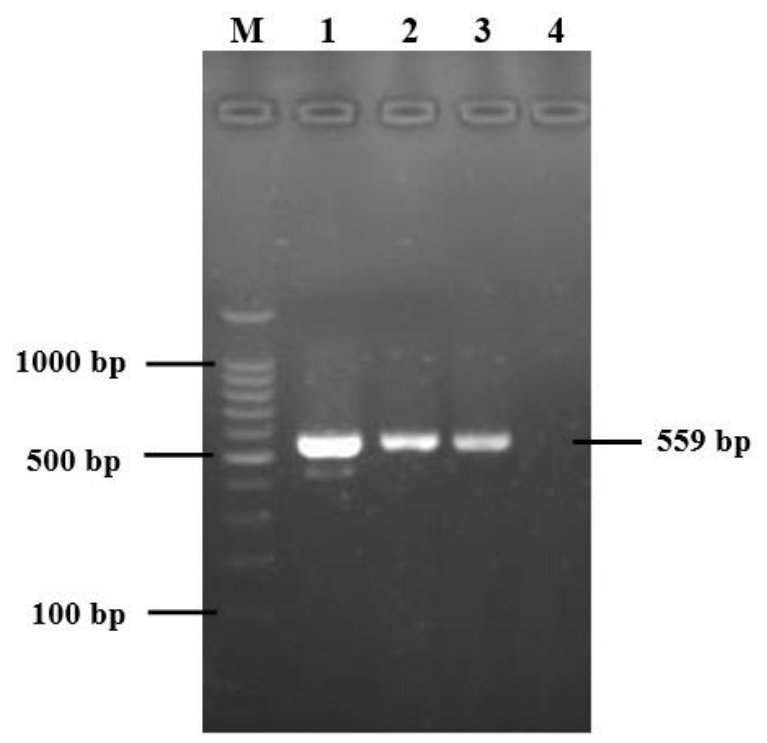

Figure 1: PCR amplification ompA gene of P. multocida isolates with amplicon $559 \mathrm{bp}$. Lane M: DNA lader $100 \mathrm{bp}$ Vivantis, 1: buffalo isolate, 2: bovine isolate, 3: Katha strain, 4: negative control.

The ompA gene local isolates and Katha strain isolate represent nucleotidesequence length of 559 bp encoding 186 amino acids. The results of homology analysis of local isolates and Katha strain isolates with GenBank data using the sucleotide BLAST program at NCBI ranged from 93 $100 \%$. The highest results in the analysis of nucleotide sequence homology between buffalo isolates and Katha strains with ompA gene of P.multocida isolates from eight ruminants: Iran (bovine, CP017961.1), India (bovine, AY903603.1), India (bovine, HQ829458.1), India (cattle, 
KU342613.1), India (calf, KU342627.1), China (yak, JQ230325.1), and India (sheep, KU342624.1). While the analysis of nucleotide sequence homology of bovine isolate with comparative ruminants isolates did not reach $100 \%$ but only reached $96 \%$ with eight ruminant isolates: India (bovine, AY903603.1), India (bovine, HQ829458.1), USA (bovine, AY643797.1), India (buffalo, KU342614.1), India (cattle, KU342613.1), India (calf, KU342627.1), China (yak, JQ230325.1) and India (sheep, KU342624.1). Phylogenetic tree analysis show that buffalo isolateand strains Katha isolate are related to bovine from India (AY903603.1,
HQ829458.1), and Iran (CP017961.1); buffalo from India (KU342614.1); yak from China (JQ230325.1); calf from India (KU342627.1); and cattle from India (KU342613.1), while bovine isolate were in different clusters with buffalo isolate and strains of Katha isolate (Figure 2).

$\mathrm{B}$ cell epitope prediction in all isolates were found five peptides. There have the same position, length, and peptide sequence with score range $1,031-1,118$. The peptides were QVSPVFAG, IPELALRVEYQ, GQSVYVPEVVSKT, LKSASVAVAG, and ANYLVAKG (Figure 3, Table 2).

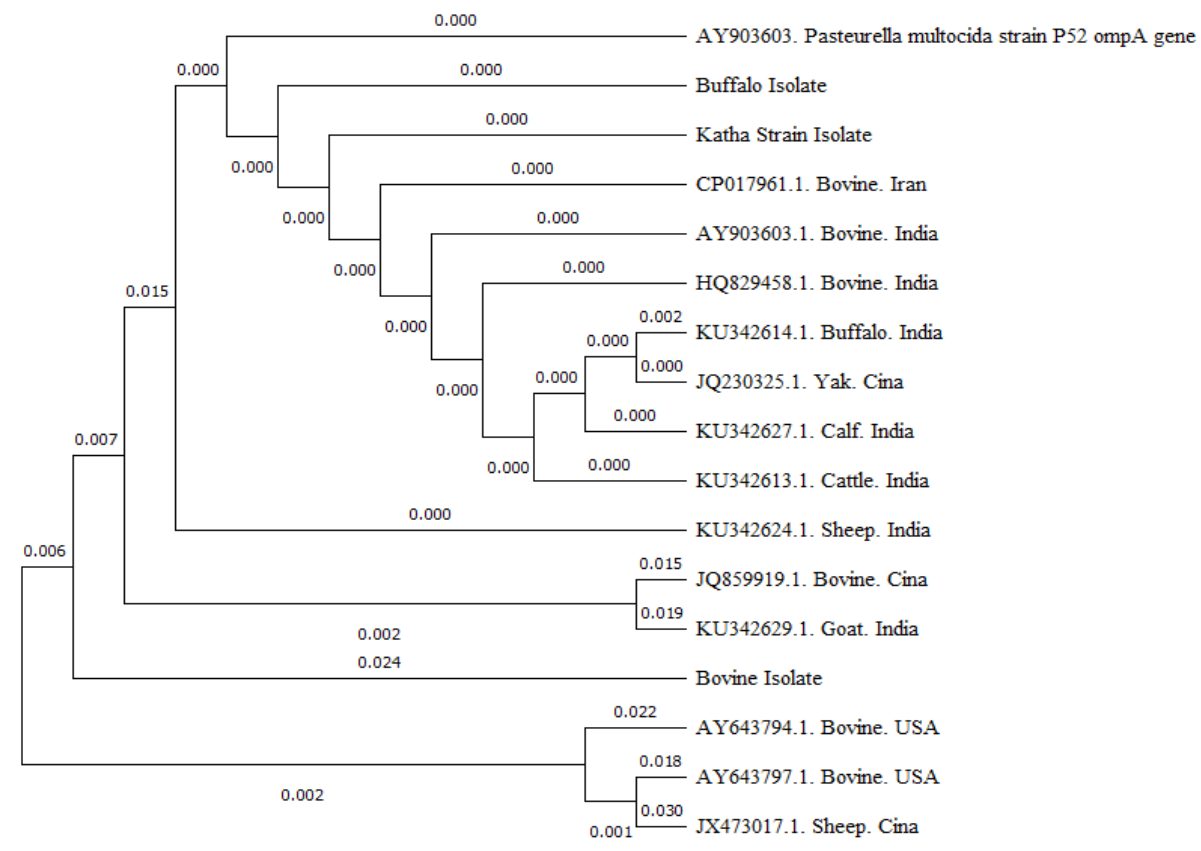

Figure 2: Phylogenetic tree neighbor joining method analysis nucleotide sequence of ompA gene P. multocida local isolates with 13 P. multocida ruminant isolates from GenBank.

Table 1: The nucleotide homology analysis of $P$. multocida ompA gene from buffalo isolate, bovine isolate, and Katha strain against comparable country ruminants isolates from GenBank

\begin{tabular}{llccc}
\hline No. & Ruminant Isolates (GenBank) & Buffalo Isolate & Bovine Isolate & Katha Strain \\
\hline 1. & CP017961.1. Bovine. Iran. & $100 \%$ & $96 \%$ & $100 \%$ \\
2. & JQ859919.1. Bovine. Cina. & $97 \%$ & $95 \%$ & $97 \%$ \\
3. & AY903603.1. Bovine.India. & $100 \%$ & $96 \%$ & $100 \%$ \\
4. & HQ829458.1. Bovine. India. & $100 \%$ & $96 \%$ & $100 \%$ \\
5. & AY643794.1. Bovine. USA & $93 \%$ & $93 \%$ & $93 \%$ \\
6. & AY643797.1. Bovine. USA. & $95 \%$ & $96 \%$ & $95 \%$ \\
7. & KU342614.1. Buffalo. India. & $99 \%$ & $96 \%$ & $99 \%$ \\
8. & KU42613.1. Cattle. India & $100 \%$ & $96 \%$ & $100 \%$ \\
9. & KU342627.1. Calf. India. & $100 \%$ & $96 \%$ & $100 \%$ \\
10. & JQ230325.1. Yak. Cina. & $100 \%$ & $96 \%$ & $100 \%$ \\
11. & KU342629.1 Goat. India. & $97 \%$ & $95 \%$ & $97 \%$ \\
12. & JX473017.1. Sheep. Cina. & $94 \%$ & $96 \%$ & $94 \%$ \\
13. & KU342624.1. Sheep. India. & $100 \%$ & & $100 \%$ \\
\hline
\end{tabular}


Iraqi Journal of Veterinary Sciences, Vol. 35, No. 2, 2021 (211-216)

Table 2: Epitopes prediction of ompA gene P.multocida from buffalo isolate, bovine isolate, and Katha strain

\begin{tabular}{llccccc}
\hline \multirow{2}{*}{ No. } & \multirow{2}{*}{ Position } & \multirow{2}{*}{ Peptida } & Long & \multicolumn{3}{c}{ Log score } \\
\cline { 5 - 6 } & & & & Buffalo isolate & Bovine isolate & Katha strain \\
\hline 1. & $4-11$ & QVSPVFAG & 8 & 1,095 & 1,095 & 1,095 \\
2. & $18-28$ & IPELALRVEYQ & 11 & 1,081 & 1,084 & 1,081 \\
3. & $62-74$ & GQSVYVPEVVSKT & 13 & 1,032 & 1,118 & 1,118 \\
4. & $108-117$ & LKSASVAVAG & 10 & 1,099 & 1,099 & 1,099 \\
5. & $140-147$ & ANYLVAKG & 8 & 1,11 & 1,11 & 1,11 \\
\hline
\end{tabular}

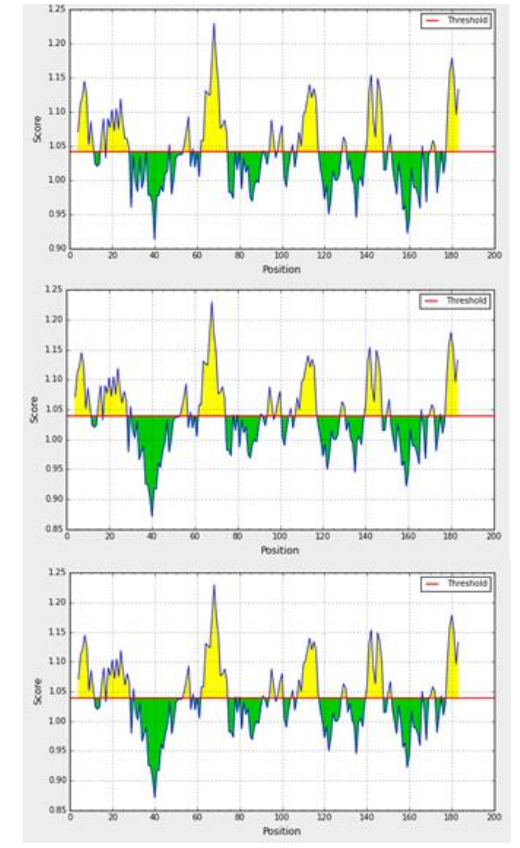

Figure 3: Graphical representation epitope prediction of ompA gene $P$. multocida. Buffalo isolate (a), bovine isolate (b), and strain Katha (c).

\section{Discussion}

This study used three sample of P.multocida isolate from buffalo and bovine from Nusa Tenggara Timur obtained from the Denpasar, Bali Veterinary Center and also P.multocida strain Katha isolate from HS vaccine. The study was conducted to see the presence of an ompA encoding gene in local isolates and Katha strain isolates, nucleotide sequences and amino acid sequences obtained from local isolates and Katha strain isolates were homologized with sequences of ruminant isolates from several countries in the world, and prediction of B cell epitopes from amino acid sequences of $P$. multocida local isolates.

The $P$. multocida local isolates were reconfirmed bacteria tests, then local isolates and Katha strain isolate determinant an ompA gene using the PCR amplification technique showing a result of 559 bp using modified primers with amplicon $201 \mathrm{bp}$ (15) and $965 \mathrm{bp}$ (16). Therefore in this study using the primers design of two different studies so that the results of the amplification obtained were $559 \mathrm{bp}$.

The results of the analysis of nucleotide sequences of buffalo isolate and Katha strain isolate showed the highest number reached $100 \%$ while bovine isolate only reached $96 \%$ with ruminant isolates from several countries in the world from GenBank. There was homogeneity of antigens in the protein profile of six isolates of P.multocida type B from cattle and buffalo (17). High homology can be used as a basic reference for candidates to use vaccines and diagnostic kits. This is due to P.multocida from isolates in Indonesia probably originating from these countries or vice versa through export and import activities from buffalo and cattle between countries (18). Low levels of diversity in OMP profiles can be attributed to genetic diversity is lacking in P.multocida isolates causes of HS $(19,20)$.

Based on the phylogenetic tree analysis results, it was found that among the ompA gene of P.multocida buffalo and strain isolate Katha had close relationships with bovine from India (AY903603.1, HQ829458.1), and Iran (CP017961.1); buffalo from India (KU342614.1); yak from China (JQ230325.1); calf from India (KU342627.1); and cattle from India (KU342613.1), while bovine isolate had a long relationship with buffalo isolate and Katha strain isolate. The smaller the scale on the phylogenetic tree, the closer the relationship. While the large scale on the phylogenetic tree, the kinship is further away. In addition, the results of homology and phylogenetic analysis in a study with a composition of $600 \mathrm{bp}$ will have different results with a longer size of nucleotides. The results of homology and phylogenetic tree analysis will be clearer and more valid with longer nucleotide sizes, because of the broader scope of nucleotide data. According to previous research (6) that molecular evolution of ompA proteins can be used to classify P.multocida isolates into various types of capsules, host types, and levels of pathogenicity. The ompA is involved in adhesion and experiences strong selective pressure, further research is needed to clarify whether polymorphisms affect protein function (16).

B cell epitope prediction of Kolaskar and Tongaonkar antigenicity method based on a single-parameter with semiempirical method which judiciously makes use of physicochemical properties of amino acid residues and experimental data, is developed to predict antigenic 
determinants, and its accuracy has been tested by application to a large number of proteins with about $75 \%$ accuracy (21). 186 amino acids from all isolates found five peptides predicted as epitope / antigenic protein with log score above 1 , the highest score is 1.118 and the lowest score is 1.084 . Interpretation of output graph (Figure 3 ) and table (Table 2) which is higher score have a probability as epitope that antigenic potential shown in the yellow graph with value above 1 (22). Epitop is very attractive for clinical and basic biomedical researchers because epitopes have great potential for vaccine design, disease prevention, diagnosis and treatment. Using rDNA technology, specific epitopes can replace overall pathogen in the vaccine (4). OMP plays an immunoprotective role and has strong potential for the development of candidate subunits vaccine against HS (23). Exploring the molecular ompA gene of P. multocida local isolates provided information about understanding the spread of $P$. multocida bacteria and control strategies using epitope-based vaccines.

\section{Conclusion}

Nucleotide sequences were compared to amino acids then by the method of Kolaskar and Tongaonkar antigenicity predicted antigens in P. multocida. B cell epitope predictions from local isolates and Katha strain were found in five peptides QVSPVFAG, IPELALRVEYQ, GQSVYVPEVVSKT, LKSASVAVAG, and ANYLVAKG.

\section{Conflict of interest}

No conflict.

\section{References}

1. Tibor M, Barbara U, Levente S, Norbert V, Ervin A, Zoltán N. ReEmergence of bovine haemorrhagic septicaemia in Hungary. Acta Vet Hungarica. 2017;65(1):41-9.

2. Astuti LS, Istiyaningsih, Khairul D, Sarji, Deden A, Neneng A, Meutia $\mathrm{H}$, Ernes A.Vaccine quality study of septicaemia epizootica (SE) of cattle from four province in Indonesia. Bulletin of Quality Testing for Animal Medicine 2015; No.23.

3. Natalia L, Priadi A. Septicemia epizootica: research and control business in cows and buffalo in Indonesia. Res Cen Ranch. 2006;1:110.

4. Ruth E, Soria G, Ricardo NG, Dania O, Govea A, Sergio RM. An overview of bioinformatics tools for epitope prediction: Implications on vaccine development. J Biomed Inform. 2015;53:405-14.

5. Ahmad TA, Amrou EE, Salah AS. B-cell epitope mapping for the design of vaccines and effective diagnostics. Trial Vaccinol. 2016;5:7183 .

6. E-kobon T, Leeanan R, Pannoi S, Anuntasomboon P, Thongkamkoon $\mathrm{P}$, Thamchaipenet A. ompA protein sequence-based typing and virulence-associated gene profiles of Pasteurella multocida isolates associated with bovine haemorrhagic septicemia and porcine pneumonic pasteurellosis in Thailand. BMC Vet Res. 2017:13:243

7. Miguel, Ferna'ndez-Rojas A, Vaca S, Reyes-Lo'pez M, Mireya de la Garza, Aguilar-Romero F, Zenteno E, Soriano-Vargas E, Negrete-
Abascal E. Outer membrane vesicles of Pasteurella multocida contain virulence factors. Microbiol Op. 2014;3(5):711-17.

8. Hatfaludi T, Al-Hasani K, Boyce JD, Adler B. Outer membrane proteins of Pasteurella multocida. Vet Microbiol. 2010;144:1-17.

9. Ramlan M, Muniandy N, No Na Y, Rasedee A. Protective potential of high molecular weight outer membrane protein of Pasteurella multocida type 6:B. Med Clin Case Rep. 2015;1(4):290-295.

10. Dabo SM, Confe, AW, Murphy GL. Outer membrane proteins of bovine Pasteurella multocida serogroup a isolates. Vet Microbiol. 1997;54(2):167-183.

11. Dabo SM, Taylor JD, Confer AW. Pasteurella multocida and bovine respiration diseases. Anim Heal Res Rev. 2007;8:129-150.

12. Tomer P, Chaturvedi GC, Minakshi M, Monga DP. Comparative analysis of the outer membrane protein profiles of isolates of the Pasteurella multocida (B:2) associated with haemorrhagic septicaemia. Vet Res Comun. 2002;26:513-22.

13. Dogra V, Verma S, Singh G, Wani AH, Chahota R, Dhar P, Verma L, Sharma, M. Development of OMP based indirect ELISA to gauge the antibody titers in bovines against Pasteurella multocida. Iranian J Vet Res. 2015;16(4):350-6.

14. Dey S, Singh VP. Outer membrane protein profiles of Indian isolates Pasteurella multocida serotype B:2. Indian J Anim Sci. 2008;78(11):1183-85.

15. Kamshat AS, Nurkuisa MR, Mukhit BO, Kainar BB, Nurlan TS. Virulence of Pasteurella multocida isolated during pasteurellosis outbreak among saigas in Kazakhstan. Curr Tren Biomed Eng Biosci. 2017;8(2):555735.

16. Vougidou C, Sandalakis V, Psaroulaki A, Siarkou V, Petridou E, Ekateriniadou L. Distribution of the ompA-Types among ruminant and swine pneumonic strains of Pasteurella multocida Exhibiting various Cap-Locus and ToxA patterns. Microbiol Res. 2015;174:1-8.

17. Johnson RB, Dawkins HJS, Spencer TL, Bascon JLT, Almazan MJPP, Agar EC, Rivera WC. Characterisation of Pasteurella multocida (haemorrhagic septicaemia) isolates from the Philippines. International Workshop on Pasteurellosis in Production Animals. Bali, Indonesia. BMC. 1993:203-08.

18. Puspito SA. Detection, homology, and prediction of capsular-encoding gen epitope Pasteurella multocida from Buffalo from NTT [MSc thesis]. Airlangga: Faculty of Veterinary Medicine. Airlangga University; 2018

19. Dutta TK, Gautam R, Singh VP, Kumar AA. Molecular characterization of Indian isolates of Pasteurella multocida serotype B:2 using REA, RAPD-PCR and ribotyping. Indian J Anim Sci. 2004;74:572-76.

20. Saxena MK, Ulnar KA, Chaudhari P, Shivachandra SB, Singh VP, Sharna B. Ribotyping of Indian isolates of Pasteurella multocida based on 16S and 23S rRNA Genes. Vet Res Comun. 2005;29:527-35.

21. Kolaskar A, Tongaonkar PC. A Semi-empirical method for prediction of antigenic determinants on protein antigens. Elsevier Sci Pub Biomed Div. 1990;276(1,2):172-174.

22. IEDB: Antibody epitope prediction - tutorial. USA: National Institutes of Health; c2005-2019.

23. Joshi S, Kamal T, Singh R. Comparative immunogenicity and protective efficacy of different preparations of Pasteurella multocida outer membrane proteins (B:2) in a mouse model. Vet Arhiv. 2013;83(6):665-76. 


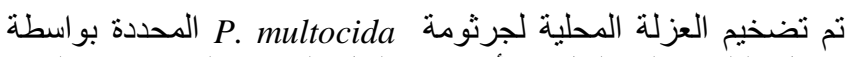

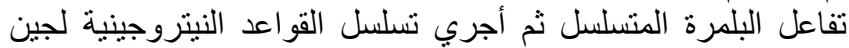
ompA

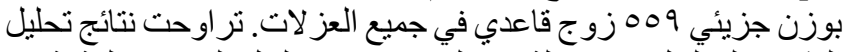

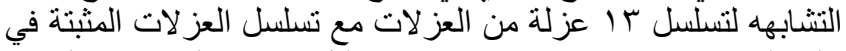

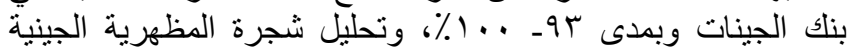

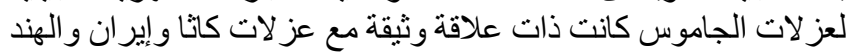

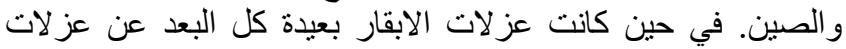

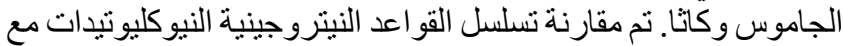

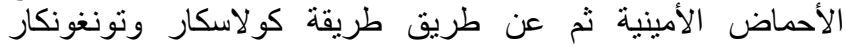

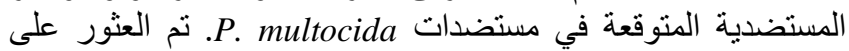
تنبؤات الخلية B من العزل المحلية وسلالة كاثا في خمس البيتيدات 'GQSVYVPEVVSKT ‘IPELALRVEYQ 'QVSPVFAG .ANYLVAKG و LKSASVAVAG

\section{التحليل الجزيئي لجين ompA للعزلات المحلية لجرثومة Pasteurella multocida}
أ. ديوي' ، أ. استوبانغيسيتي' ، س. سوارنو، دي. هاندياتنو '، ر.

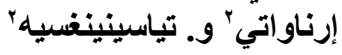

' فرع الصحة العامة البيطرية، ` فرع الأحياء المجهرية البيطرية، كلية الطب البيطري، جامعة اير لانكا، سور ابايا، إندونيسياء الفرانيا

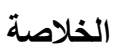

الهدف من هذا البحث هو التحليل الجزيئي لجين ompA لجرثومة Pasteurella multocida نغار اتيمور، إندونيسيا وسلالة كاثا المعزولة من لقاح تنمم الدم النزفي. 